\title{
Empirical Relationships on Mechanical Properties of Class-F Fly Ash and GGBS Based Geopolymer Concrete
}

\author{
Ramamohana Reddy Bellum*, Karthikeyan Muniraj, Sri Rama Chand Madduru \\ Department of Civil Engineering, Vignan's Foundation for Science, Technology \& Research, Vadlamudi, Guntur 522213, India
}

Corresponding Author Email: rammohanbellum92@gmail.com

https://doi.org/10.18280/acsm.430308

Received: 8 March 2019

Accepted: 1 June 2019

\section{Keywords:}

fly ash, GGBS, modulus of elasticity, geopolymer concrete, ambient curing

\begin{abstract}
Ordinary Portland Cement (OPC) is one of the important materials used in the development of the construction industry. Production of OPC consumes lot of raw materials, emits extreme quantity of carbon dioxide $\left(\mathrm{CO}_{2}\right)$ into atmosphere and highly energy-intensive. Thus, to reduce the production of cement so many attempts are done and an alternative binder was found. The alternative to cement concrete is geopolymer concrete (GC) and it is produced by mixing industrial by-products (rich in aluminosilicate) with an alkaline solution. This paper explores the mechanical properties and a representative non-linear equation was proposed for the relationship between splitting tensile Vs compressive strengths and flexural Vs compressive strengths of fly ash-GGBS synthesized GC cured at ambient temperature for 28 days. This work also presents empirical formulae for predicting elastic modulus of fly ash-GGBS synthesized GC. Equations were proposed to determine the splitting tensile strength, flexural strength and elastic modulus based on the compressive strength of GC. The obtained results are clearly indicating that the predicted (from proposed equations) splitting tensile and flexural strength values are very close to the experimental values. It is established that the formulae found in various codes and literature generally predict the higher values of the elastic modulus than those obtained using the proposed equation.
\end{abstract}

\section{INTRODUCTION}

Geopolymer Concrete (GC) is an emerging alternative to conventional cement-based concrete with an eco-friendly environment. It possible to improve sustainable utilization of industrial by-products in construction [1-2]. Several investigations have been done on the improvement of GC synthesized from dissimilar aluminosilicate source materials [2-7]. GC is produced by the reaction of different aluminosilicate materials such as fly ash and Ground Granulated Blast Furnace Slag (GGBS) with an alkaline solution [7-8]. Use of industrial by-products in the making of $\mathrm{GC}$ can contribute to the reduction of $\mathrm{CO}_{2}$ emissions caused by cement production [9-10]. The micro-structural growth and mechanical properties of GC in geo-polymerization are mainly depending on the chemical composition of byproducts and the type of alkaline solution used to produce geopolymers [11-12]. OPC or PPC cement mainly form C-S$\mathrm{H}$ gel, while geopolymer resin mainly consists of an aluminosilicate gel. This difference shows the outstanding advantages of geopolymer binder over the OPC binder [13]. GC has been reported to obtain superior engineering properties and durability characteristics, also as good as ordinary concrete in several cases of structural applications [14-21].

The state of the reports on GC undoubtedly indicated that purely fly ash synthesized GC requires additional supply of heat $\left(60-90{ }^{\circ} \mathrm{C}\right.$ temperature of curing) for a minimum of 24 hours to attain required strength [22-24]. With the inclusion of GGBS or any other industrial by-product, it is understood that the supply of heat can be eradicated and can achieve necessitated strength properties [22]. The flexural and splitting tensile strengths of GC samples are favorably related to that of conventional concrete specimens and also noted that strength parameters of GC samples are depending on the mix proportions and curing conditions [25]. Engineering properties of GC activated with different activators and a silicate ion present in the activator solutions enhanced strength and young's modulus values [26]. The elastic modulus of concrete is an important factor to evaluate construction applications and service life [5]. Elastic modulus of OPC concrete ranges between 30300-34500 MPa, whereas in GC it was found that 10700-18400 MPa [26]. Young's modulus of low-calcium based geopolymer specimen's ranges between 23000-30800 $\mathrm{MPa}$ [27]. Alkali activated pulverized fuel ash binder has lower young's modulus values compared to OPC as well as geopolymer binders [28]. Initial 14 days the moduli of elasticity for alkali-activated pozzolan specimens are lower compared to OPC specimens and in a longer time, the values are increased up to 10-20\% [29]. Hence a huge dissimilarity in the elastic modulus of GC was identified in the earlier literature.

\section{MATERIALS}

\subsection{Binders}

Fly ash is the by-product produced from coal burning in the generation of electricity like thermal power plants [30]; annually more than 220 million tonnes of fly ash is producing in India [31]. Fly ash used in this research was taken from 
NTPC-Vijayawada, India and GGBS were taken from JSW Cements Ltd, Vijayawada, India. The oxide composition of Fly ash and GGBS was determined by XRF analysis is shown in Table 1. Specific gravity and specific surface area of different materials used in this paper are shown in Table 2.

\subsection{Alkaline solution}

The mixture of sodium silicate and sodium hydroxide in a mass ratio of 2.0 was used as an alkaline solution. $\mathrm{NaOH}$ in flakes form obtained from Vamshi Krishna chemical solutions, Vijayawada and $\mathrm{Na}_{2} \mathrm{SiO}_{3}$ in solution form taken from Kiran Global Solutions, Hyderabad are used. The concentration of $\mathrm{NaOH}$ solution was maintained as constant i.e., $8 \mathrm{M}$. Alkaline activator solution will be prepared at least 24 hours before casting the specimens to get desired results [22]. In order to achieve higher strength geopolymer concrete, the most advantageous range of sodium silicate to sodium hydroxide was 0.67 to 1.00 [32]. Economic point of view sodium silicate to sodium hydroxide ratio and binder to alkaline activator solution percentage maintained as 2.0 and 0.40 , respectively for all the mixes in this research work. Alkaline solution (Sodium hydroxide solution mixed with sodium silicate solution) should be prepared one day before making of GC specimens to get desired results [33].

\subsection{Aggregates}

Aggregates are one of the principal components of concrete since it occupies almost three-quarters of the volume of concrete. The quality of aggregates used in concrete invariably affects the quality of the final concrete. In this paper, Krishna river sand in the surface dry condition is used as fine aggregate and coarse aggregates are sourced from local dealers in Guntur, A.P., India. The sieve analysis tests were carried out according to IS 2386-1963 (Part I) [34] on aggregates to determine the conformation to IS 383-2016 [35]. The coarse aggregates of less than $20 \mathrm{~mm}$ size were used in all mixes of GC. Sieve analysis is conducted on the mixed coarse aggregate sample. The result obtained on sieve analysis of coarse and fine aggregates is presented in Table 3 and Table 4, respectively.

\subsection{Mix proportions of GC}

The mix proportion for M20 grade of GC is carried out according to the previous mix design procedures and Indian standard code [36-38]. Table 5 shows the mix proportioning of different materials used in this research work.

Table 1. Major oxide composition of fly ash and GGBS determined by XRF analysis

\begin{tabular}{ccccccccccccc}
\hline Oxide & $\mathrm{Al}_{2} \mathrm{O}_{3}$ & $\mathbf{C a O}$ & $\mathrm{Fe}_{2} \mathrm{O}_{3}$ & $\mathrm{SiO}_{2}$ & $\mathbf{P}_{2} \mathrm{O}_{5}$ & $\mathbf{S O}_{3}$ & $\mathbf{M g O}$ & $\mathrm{Na}_{2} \mathrm{O}$ & $\mathrm{K}_{2} \mathrm{O}$ & $\mathrm{TiO}_{2}$ & $\mathrm{MnO}$ & $\mathbf{L O I}$ \\
\hline $\mathbf{F l y}$ & 25.08 & 2.87 & 4.56 & 58.23 & 0.2 & 1.16 & 1.21 & 0.41 & 0.87 & 0.83 & 2.94 & 1.59 \\
$\mathbf{a s h}$ & 12.14 & 44.71 & 1.10 & 32.25 & - & 0.84 & 4.23 & 0.87 & - & - & 1.96 & 1.98 \\
\hline
\end{tabular}

Table 2. Properties of different materials (specific gravity and specific surface area)

\begin{tabular}{cccccccc}
\hline Material & Fly ash & GGBS & $\begin{array}{c}\text { Sodium } \\
\text { hydroxide }\end{array}$ & $\begin{array}{c}\text { Sodium } \\
\text { silicate }\end{array}$ & $\begin{array}{c}\text { Coarse } \\
\text { aggregates }\end{array}$ & $\begin{array}{c}\text { Fine } \\
\text { aggregates }\end{array}$ & Water \\
\hline $\begin{array}{c}\text { Specific Gravity } \\
\text { Specific }\end{array}$ & 2.31 & 2.8 & 2.13 & 1.53 & 2.8 & 2.63 & 1 \\
surface area $\left(\mathbf{m}^{2} / \mathbf{k g}\right)$ & 367 & 508 & - & - & - & - & - \\
\hline
\end{tabular}

Table 3. Sieve analysis of coarse aggregate

\begin{tabular}{ccccccc}
\hline $\begin{array}{c}\text { IS sieve size } \\
(\mathbf{m m})\end{array}$ & $\begin{array}{c}\text { Weight retained } \\
(\mathbf{g m})\end{array}$ & $\begin{array}{c}\text { Percentage } \\
\text { retained }\end{array}$ & $\begin{array}{c}\text { Cumulative } \\
\text { \% retained }\end{array}$ & $\begin{array}{c}\text { Cumulative } \\
\text { \% passing }\end{array}$ & $\begin{array}{c}\text { Limit as per } \\
\text { IS 383-2016 }\end{array}$ & Remarks \\
\hline 40 & 0 & 0 & 0 & 100 & 100 & Aggregates \\
20 & 1107 & 11.07 & 11.07 & 88.93 & $85-100$ & conform to 20mm \\
10 & 7060 & 70.60 & 81.70 & 18.3 & $0-20$ & nominal maximum \\
4.75 & 1816 & 18.16 & 99.86 & 0.14 & $0-5$ & size CA \\
Pan & 14 & 0.14 & 100 & 0 & 0 & \\
\hline
\end{tabular}

Table 4. Sieve analysis of fine aggregate

\begin{tabular}{ccccccc}
\hline $\begin{array}{c}\text { IS sieve size } \\
(\mathbf{m m})\end{array}$ & $\begin{array}{c}\text { Weight retained } \\
(\mathbf{g m})\end{array}$ & $\begin{array}{c}\text { Percentage } \\
\text { retained }\end{array}$ & $\begin{array}{c}\text { Cumulative } \\
\text { \% retained }\end{array}$ & $\begin{array}{c}\text { Cumulative } \\
\text { \% passing }\end{array}$ & $\begin{array}{c}\text { Limit as per } \\
\text { IS 383-2016 }\end{array}$ & Remarks \\
\hline 10 & 0 & 0 & 0 & 100 & 100 & \\
4.75 & 14 & 1.4 & 1.4 & 98.6 & $90-100$ & Aggregates \\
2.36 & 181 & 18.1 & 19.5 & 80.5 & $75-100$ & conform to Zone II \\
1.18 & 184 & 18.4 & 37.9 & 62.1 & $55-90$ & of IS: $383-2016$ \\
0.6 & 251 & 25.1 & 63 & 37 & $35-59$ & \\
0.3 & 193 & 19.3 & 82.3 & 17.7 & $8-30$ & \\
0.15 & 148 & 14.8 & 97.1 & 2.9 & $0-10$ & \\
\hline
\end{tabular}


Table 5. Mix proportions of different materials $\left(\mathrm{kg} / \mathrm{m}^{3}\right)$

\begin{tabular}{cccccccc}
\hline Mix Id & Fly ash & GGBS & $\begin{array}{c}\text { Fine } \\
\text { aggregate }\end{array}$ & $\begin{array}{c}\text { Coarse } \\
\text { aggregate }\end{array}$ & $\begin{array}{c}\text { Sodium } \\
\text { hydroxide } \\
(\mathbf{8 M})\end{array}$ & $\begin{array}{c}\text { Sodium } \\
\text { silicate }\end{array}$ & $\begin{array}{c}\text { Alkaline } \\
\text { solution/ } \\
\text { Binder (s/b) }\end{array}$ \\
\hline $\mathrm{F}_{100} \mathrm{G}_{0}$ & 407 & 0 & 610.5 & 1221 & 54.26 & 108.53 & 0.4 \\
$\mathrm{~F}_{90} \mathrm{G}_{10}$ & 366.3 & 40.7 & 610.5 & 1221 & 54.26 & 108.53 & 0.4 \\
$\mathrm{~F}_{80} \mathrm{G}_{20}$ & 325.6 & 81.4 & 610.5 & 1221 & 54.26 & 108.53 & 0.4 \\
$\mathrm{~F}_{70} \mathrm{G}_{30}$ & 284.9 & 122.1 & 610.5 & 1221 & 54.26 & 108.53 & 0.4 \\
$\mathrm{~F}_{60} \mathrm{G}_{40}$ & 244.2 & 162.8 & 610.5 & 1221 & 54.26 & 108.53 & 0.4 \\
$\mathrm{~F}_{50} \mathrm{G}_{50}$ & 203.5 & 203.5 & 610.5 & 1221 & 54.26 & 108.53 & 0.4 \\
$\mathrm{~F}_{40} \mathrm{G}_{60}$ & 162.8 & 244.2 & 610.5 & 1221 & 54.26 & 108.53 & 0.4 \\
$\mathrm{~F}_{30} \mathrm{G}_{70}$ & 122.1 & 284.9 & 610.5 & 1221 & 54.26 & 108.53 & 0.4 \\
\hline
\end{tabular}

\subsection{Mixing and casting}

Fly ash, other industrial by-products (like GGBS, Silica fume, Red mud, Zeolite), and alkaline solution were mixed mutually into a homogenous binder. The binder was then introduced into the dry sand and mixed for 30-40 seconds. Afterward, aggregates of size less than $20 \mathrm{~mm}$ were added to the mixture and uniformly mixed for 2-2.5 minutes. After mixing of all these materials, GC was transferred into moulds (cube, cylinder and beam) and Due to less setting time of GC, a vibration machine was used to eliminate air attentive in the specimens.

\subsection{Workability of GC}

The workability of fresh GC mixtures was calculated instantaneously after mixing by a slump cone test according to IS 1199-1959 [39]. An Abrams slump cone of dimensions was $300 \mathrm{~mm}$ in height, and $100 \mathrm{~mm}$ and $200 \mathrm{~mm}$ in diameters at the top and bottom, respectively. It was observed that workability of GC slightly increased by adding $0.75 \%$ of water (i.e. $60 \mathrm{ml}$ ) for all mixes. All mixes of $\mathrm{GC}$ were a medium range of degree of workability was observed and workability values are less than $75 \mathrm{~mm}$ is shown in Table 6 .

Table 6. Workability of Fly ash-GGBS based GC

\begin{tabular}{lcc}
\hline Mix Id & Slump value & $\begin{array}{c}\text { Degree of } \\
\text { workability }\end{array}$ \\
\hline $\mathrm{F}_{100} \mathrm{G}_{0}$ & 82 & \\
$\mathrm{~F}_{90} \mathrm{G}_{10}$ & 75 & \\
$\mathrm{~F}_{80} \mathrm{G}_{20}$ & 68 & \\
$\mathrm{~F}_{70} \mathrm{G}_{30}$ & 55 & Medium \\
$\mathrm{F}_{60} \mathrm{G}_{40}$ & 54 & \\
$\mathrm{~F}_{50} \mathrm{G}_{50}$ & 55 & \\
$\mathrm{~F}_{40} \mathrm{G}_{60}$ & 51 & \\
$\mathrm{~F}_{30} \mathrm{G}_{70}$ & 51 & \\
\hline
\end{tabular}

\subsection{Curing and testing}

Compression testing (2000 kN capacity) and flexural testing machines $(100 \mathrm{kN})$ are used to find the mechanical properties of GC. To determine the compressive strength of GC cubes Indian standard code was used IS 516 (1959) [40] Splitting tensile strength of cylindrical specimens is carried according to the prescribed specifications of ASTM C496/ C496M-17 [41]. Flexural strength of prism/beam specimens is tested with Third-Point Loading as per American standard test procedure ASTM C78/C78M-18 [42]. There is no necessity of exposing GC specimens to elevated temperatures to gain maximum strength if the smallest amount $(9 \%$ minimum) of fly ash is replaced by GGBS. In this paper, ambient curing condition was followed to cure the specimens at a temperature of $32 \pm 3{ }^{\circ} \mathrm{C}$ for $7,14,21$ and 28 days.

\section{MECHANICAL PROPERTIES}

The mechanical properties of GC are increased by an increase in the quantity of fly ash fineness [43]. The fineness (in terms of a specific surface) of fly ash taken in this work was $367 \mathrm{~m}^{2} / \mathrm{kg}$, to improve the strength properties of GC. Fly ash and GGBS based GC showed greater mechanical properties while increasing the GGBS (up to $70 \%$ ) content strength was also increased [14-15,44-45]. Setting time of pure fly ash-based $\mathrm{GC}$ at room temperature may take more than 40 hours to set [46]. Thus, it was observed that the addition of GGBS in fly ash-based GC will help to improve the setting time and strength.

\subsection{Compressive strength}

Standard cubical moulds $(150 \times 150 \times 150 \mathrm{~mm})$ are used to determine the compressive strength [40] of GC for 7, 14, 21 and 28 days of ambient curing. The obtained results at dissimilar proportions of GC are shown in Figure 1. The target strength obtained in mix design is $26.6 \mathrm{~N} / \mathrm{mm}^{2}$, but for $\mathrm{GC}$ at a mix proportion F30G70 given highest compressive strength i.e. $38.34 \mathrm{MPa}$ at 28 days of ambient curing.

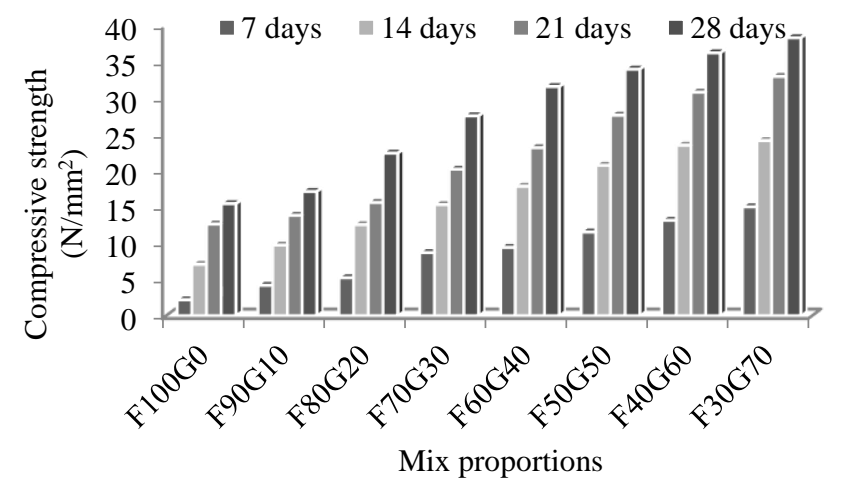

Figure 1. Compressive Strength of GC at different mix proportions and curing ages

\subsection{Splitting tensile strength}

Cylindrical specimens $(300 \times 150 \mathrm{~mm})$ are used to know the strength of GC with different mix proportions and curing ages. Generally, the tensile strength of conventional concrete varies between $10-15 \%$ of compressive strength i.e. tensile strength of M20 grade concrete is 2-3 MPa. It was observed 
that $\mathrm{GC}$ specimens are gaining greater tensile strength up to $15-20 \%$ of compressive strength i.e. 2-6 MPa for 28 days of ambient curing. $30 \%$ Fly ash and $70 \%$ GGBS based GC specimens showed 6.68 $\mathrm{MPa}$ splitting tensile strength at 28 days of curing (Figure 2).

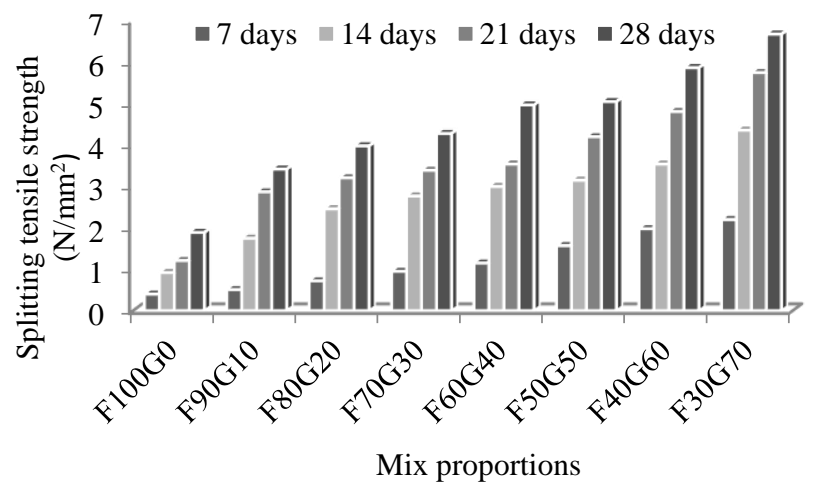

Figure 2. Splitting tensile strength of GC at different mix proportions and curing ages

\subsection{Flexural strength}

To determine the flexural strength of GC beam moulds of size $100 \times 100 \times 500 \mathrm{~mm}$ was used and rate of load applied at a rate of loading of $400 \mathrm{~kg} / \mathrm{min}$. Conventional concrete flexural strength varies between $15-25 \%$ of compressive strength i.e. for M20 grade is in between 3-5 MPa (Figure 3).

$$
f_{b}=\frac{3 p l}{2 b d^{2}}
$$

where, $f_{b}=$ Flexural Strength, $p=$ Ultimate load $(\mathrm{KN}), \mathrm{l}=$ Supported length $(\mathrm{mm}), \mathrm{b}=$ Width of the beam specimen $(\mathrm{mm}), \mathrm{d}=$ Depth of the beam specimen $(\mathrm{mm})$.

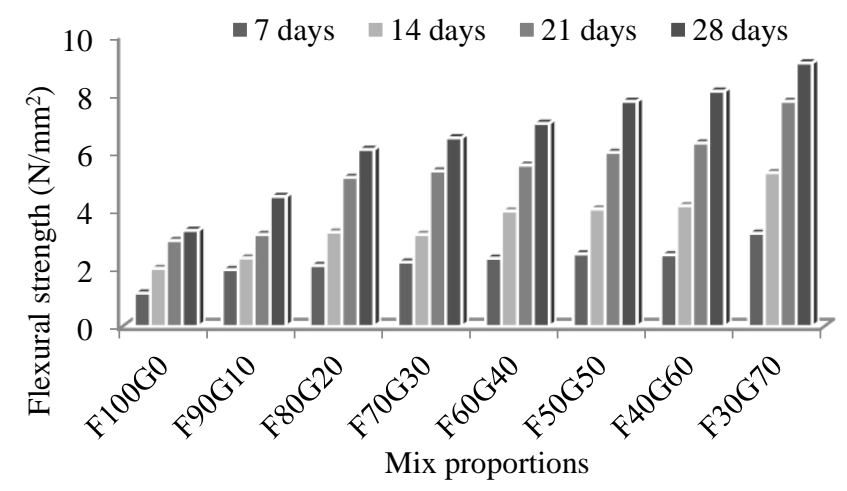

Figure 3. Flexural strength of GC at different mix proportions and curing ages

\subsection{Comparison between predicted and experimental values of GC}

According to several codes and researchers splitting tensile and flexural strengths of concrete is strongly associated with that of compressive strength [47-57]. The correlation between splitting tensile strength and compressive strength of concrete can be represented by non-linear equations because the tensile or flexural strengths of concrete increases with an increase in compressive strength and the ratio of tensile strength to compressive strength decreases as the compressive strength increase [58]. This implies that regression analysis using the least square fit method was adopted for the non-linear relationship between split tensile, flexural strengths of GC from compressive strength. Table 7 and 8 shows the predicted values of splitting tensile strength and flexural strength of GC from codes, literature and proposed equation.

\subsection{Predicted splitting tensile and flexural strengths from experimental compressive strength}

Design of concrete structures recommended certain standard equations to predict the splitting tensile and flexural strength from compressive strength. The recommended equations in the American Concrete Institute (ACI) and some other research papers were used to predict splitting tensile and flexural strengths of GC specimens. The ACI 363R-92 [48] and ACI 318-99 [49] recommends respective Eq. (1) and Eq. (2) as the appropriate relationship between the splitting tensile strength and compressive strength. Similarly, Eq. (3) and Eq. (4) recommends an approximate relationship between flexural strength and compressive strength. Not only ACI code some previous research papers also proposed few equations in associated with splitting tensile, flexural strengths from compressive strengths are shown in Figure 4 and 5. The proposed Eq. 5 and Eq. 6 shows the relationship between splitting tensile, flexural strengths of GC from compressive strength.

$$
\begin{aligned}
& f_{t}=0.59 \sqrt{f_{c}} \\
& f_{t}=0.56 \sqrt{f_{c}} \\
& f_{f t}=0.94 \sqrt{f_{c}} \\
& f_{f t}=0.62 \sqrt{f_{c}} \\
& f_{t}=0.51 f_{c}^{0.66} \\
& f_{f t}=0.57 f_{c}^{0.74}
\end{aligned}
$$

where, $f_{t}=$ Splitting tensile strength (Predicted), $f_{\mathrm{ft}}=$ Flexural strength (Predicted), $\mathrm{f}_{\mathrm{c}}=$ Compressive strength (Experimental)

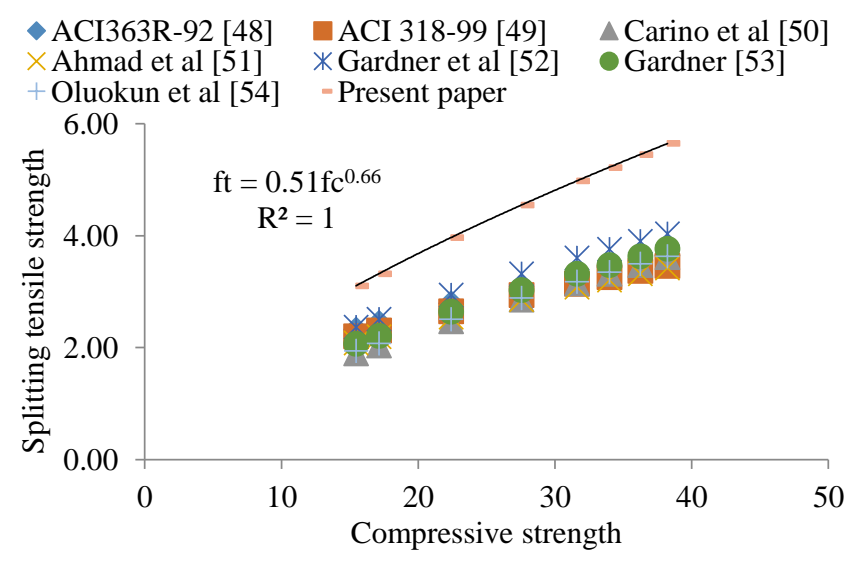

Figure 4. Comparison of predicted splitting tensile strength values 
Table 7. Predicted splitting tensile strength for several relationships

\begin{tabular}{|c|c|c|c|c|c|c|c|c|c|c|}
\hline \multirow[b]{3}{*}{ Mix Id } & \multirow{2}{*}{\multicolumn{2}{|c|}{ Experimental data }} & \multicolumn{8}{|c|}{ Predicted data } \\
\hline & & & $\begin{array}{c}\text { ACI363R- } \\
92[48]\end{array}$ & $\begin{array}{c}\text { ACI 318- } \\
99[49]\end{array}$ & $\begin{array}{c}\text { Carino et al } \\
{[50]} \\
\end{array}$ & $\begin{array}{c}\text { Ahmad et } \\
\text { al [51] }\end{array}$ & $\begin{array}{c}\text { Gardner et } \\
\text { al [52] }\end{array}$ & $\begin{array}{c}\text { Gardner } \\
{[53]} \\
\end{array}$ & $\begin{array}{c}\text { Oluokun et } \\
\text { al [54] }\end{array}$ & $\begin{array}{c}\text { Present } \\
\text { paper }\end{array}$ \\
\hline & $\begin{array}{c}\text { Compressive } \\
\text { strength } \\
\left(\mathbf{N} / \mathbf{m m}^{2}\right)\end{array}$ & $\begin{array}{l}\text { Splitting } \\
\text { tensile } \\
\text { strength } \\
\left(\mathrm{N} / \mathrm{mm}^{2}\right)\end{array}$ & $f_{t}=0.59 f^{0.5}$ & $f_{t}=0.56 f^{0.5}$ & $f_{t}=0.272 f^{0.71}$ & $\begin{array}{c}\mathbf{f}_{\mathbf{t}} \\
=0.462 \mathrm{fc}^{0.55}\end{array}$ & $f_{t}=0.47 f^{0.59}$ & $\begin{array}{c}f_{t}= \\
0.34 \mathrm{fc}^{0.66}\end{array}$ & $\begin{array}{c}f_{t}=0.294 \\
f^{0.69}\end{array}$ & $\begin{array}{c}f_{t}=0.51 \\
f^{0.66}\end{array}$ \\
\hline$F_{100} G_{0}$ & 15.46 & 1.89 & 2.32 & 2.20 & 1.90 & 2.08 & 2.36 & 2.07 & 1.94 & 3.11 \\
\hline $\mathbf{F}_{90} \mathbf{G}_{10}$ & 17.14 & 3.42 & 2.44 & 2.31 & 2.04 & 2.2 & 2.51 & 2.21 & 2.08 & 3.32 \\
\hline $\mathbf{F}_{80} \mathbf{G}_{20}$ & 22.43 & 3.98 & 2.79 & 2.65 & 2.47 & 2.55 & 2.94 & 2.64 & 2.51 & 3.97 \\
\hline $\mathbf{F}_{70} \mathbf{G}_{30}$ & 27.58 & 4.28 & 3.09 & 2.94 & 2.86 & 2.86 & 3.32 & 3.03 & 2.89 & 4.55 \\
\hline$F_{60} G_{40}$ & 31.61 & 4.97 & 3.31 & 3.14 & 3.15 & 3.08 & 3.6 & 3.32 & 3.18 & 4.98 \\
\hline $\mathbf{F}_{50} \mathbf{G}_{50}$ & 34 & 5.05 & 3.44 & 3.26 & 3.32 & 3.21 & 3.76 & 3.48 & 3.35 & 5.22 \\
\hline$F_{40} G_{60}$ & 36.25 & 5.87 & 3.55 & 3.37 & 3.48 & 3.32 & 3.9 & 3.63 & 3.5 & 5.45 \\
\hline $\mathbf{F}_{\mathbf{3 0}} \mathbf{G}_{70}$ & 38.24 & 6.68 & 3.65 & 3.46 & 3.62 & 3.43 & 4.03 & 3.77 & 3.63 & 5.65 \\
\hline
\end{tabular}

Table 8. Predicted flexural strength for several relationships

\begin{tabular}{|c|c|c|c|c|c|c|c|c|}
\hline \multirow{3}{*}{ Mix Id } & \multirow{2}{*}{\multicolumn{2}{|c|}{ Experimental data }} & \multicolumn{6}{|c|}{ Predicted data } \\
\hline & & & \multirow{2}{*}{$\begin{array}{c}\begin{array}{c}\text { ACI363R- } \\
92[48]\end{array} \\
\mathbf{f}_{\mathrm{fs}}=0.94 \mathrm{fc}^{0.5}\end{array}$} & \multirow{2}{*}{$\begin{array}{c}\begin{array}{c}\mathrm{ACI} 318- \\
99[49]\end{array} \\
\mathbf{f}_{\mathrm{fs}}=0.62 \mathrm{fc}^{0.5}\end{array}$} & \multirow{2}{*}{$\begin{array}{c}\begin{array}{c}\text { Mhaiskar } \\
\text { and Naik } \\
{[55]}\end{array} \\
\mathbf{f}_{\mathrm{fs}}=\mathbf{0 . 8 6 4 f \mathrm { fc } ^ { 0 . 5 }}\end{array}$} & \multirow{2}{*}{$\begin{array}{c}\begin{array}{c}\text { M. Ahmed } \\
{[56]}\end{array} \\
\mathbf{f}_{\mathrm{fs}}=1.055 \mathrm{fc}^{0.5}\end{array}$} & \multirow{2}{*}{$\begin{array}{c}\begin{array}{c}\text { M. Irwan } \\
\text { Juki [57] }\end{array} \\
\mathbf{f}_{\mathrm{fs}}=\mathbf{0 . 4 6 6 f \mathbf { f } ^ { 0 . 7 0 3 }}\end{array}$} & \multirow{2}{*}{$\begin{array}{c}\begin{array}{c}\text { Present } \\
\text { paper }\end{array} \\
\mathbf{f}_{\mathrm{fs}}=\mathbf{0 . 5 7 \mathbf { f c } ^ { 0 . 7 4 }}\end{array}$} \\
\hline & $\begin{array}{c}\text { Compressive } \\
\text { strength } \\
\left(\mathrm{N} / \mathrm{mm}^{2}\right) \\
\end{array}$ & $\begin{array}{l}\text { Flexural } \\
\text { strength } \\
\left(\mathrm{N} / \mathrm{mm}^{2}\right) \\
\end{array}$ & & & & & & \\
\hline $\mathbf{F}_{100} \mathbf{G}_{0}$ & 15.46 & 3.31 & 3.70 & 2.44 & 3.40 & 4.15 & 3.19 & 4.32 \\
\hline $\mathbf{F}_{90} \mathbf{G}_{10}$ & 17.14 & 4.48 & 3.89 & 2.57 & 3.58 & 4.37 & 3.43 & 4.67 \\
\hline $\mathbf{F}_{80} \mathbf{G}_{20}$ & 22.43 & 6.1 & 4.45 & 2.94 & 4.09 & 5.00 & 4.15 & 5.69 \\
\hline $\mathbf{F}_{70} \mathbf{G}_{30}$ & 27.58 & 6.5 & 4.94 & 3.26 & 4.54 & 5.54 & 4.80 & 6.64 \\
\hline$F_{60} G_{40}$ & 31.61 & 7 & 5.28 & 3.49 & 4.86 & 5.93 & 5.28 & 7.34 \\
\hline $\mathbf{F}_{50} \mathbf{G}_{50}$ & 34 & 7.76 & 5.48 & 3.62 & 5.04 & 6.15 & 5.56 & 7.75 \\
\hline $\mathbf{F}_{\mathbf{4 0}} \mathbf{G}_{60}$ & 36.25 & 8.11 & 5.66 & 3.73 & 5.20 & 6.35 & 5.82 & 8.12 \\
\hline $\mathbf{F}_{30} \mathbf{G}_{70}$ & 38.24 & 9.08 & 5.81 & 3.83 & 5.34 & 6.52 & 6.04 & 8.45 \\
\hline
\end{tabular}

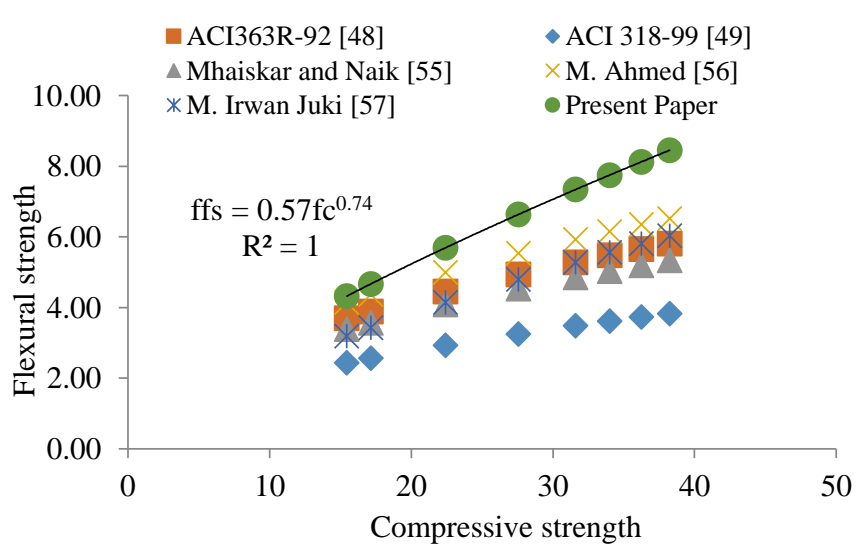

Figure 5. Comparison of predicted flexural strength values

\section{MODULUS OF ELASTICITY}

Young's modulus measures the resistance of any material against elastic deformation when a load is applied. The Young's modulus of GC was tested according to ASTM C469/C469M-10 [47]. The experiment was done with cylindrical specimens of $150 \mathrm{~mm}$ in diameter and $300 \mathrm{~mm}$ in height and three specimens are tested at each age. The mean value of the elastic modulus for 28 days is determined for GC. Generally, young's modulus values vary with respect to compressive strength. With the increases of compressive strength of concrete young's modulus values of concrete will also be increasing. Young's modulus of GC values is relatively low compared to conventional concrete of parallel compressive strength [59]. According to IS 456-2000 [60] the modulus of elasticity of conventional concrete (M20) for 28 days is $22360.68 \mathrm{MPa}$. Whereas modulus of elasticity of different mixes $\left(\mathrm{F}_{100} \mathrm{G}_{0}, \mathrm{~F}_{90} \mathrm{G}_{10}, \mathrm{~F}_{80} \mathrm{G}_{20}, \mathrm{~F}_{70} \mathrm{G}_{30}, \mathrm{~F}_{60} \mathrm{G}_{40}, \mathrm{~F}_{50} \mathrm{G}_{50}\right.$, $\mathrm{F}_{40} \mathrm{G}_{60}$ and $\mathrm{F}_{30} \mathrm{G}_{70}$ ) based $\mathrm{GC}$ ranges between 1336220196.34 MPa. The experimental data shows that young's modulus of GC was $20-40 \%$ less compared to conventional concrete.

Oven cured fly ash based GC specimens are reported to have less young's modulus values as compared to conventional concrete [25-26]. Oven cured fly ash based GC specimens of average compressive strength about $55 \mathrm{MPa}$ showed young's modulus values between 14.9-28.8 \% lower than conventional concrete [61].

Comparing the modulus of elasticity of GC specimens, much significant difference was observed due to variation in the GGBS content. By the increase of GGBS content in the GC mix modulus of elasticity was also increased. Pure fly ash-based GC specimens were showed lower compressive strength as well as young's modulus at ambient curing.

The experimental data are compared with predicted young's modulus values by the equations proposed in different codes and by earlier research papers are as given below.

(i) Based to the ACI 318-14 (ACI Building Code) [62] the young's modulus of conventional concrete (density ranges from 1442 to $2483 \mathrm{~kg} / \mathrm{m}^{3}$ ) can be determined by using Eq. (7).

$$
\mathrm{E}_{\mathrm{C}}=0.043 \times \rho^{1.5} \times \sqrt{\mathrm{f}_{\mathrm{c}}}
$$

where, $\mathrm{E}_{\mathrm{c}}=$ Young's Modulus (MPa); $\rho=$ Concrete Density $\left(\mathrm{kg} / \mathrm{m}^{3}\right) ; \mathrm{f}_{\mathrm{c}}=$ Concrete Compressive strength (MPa), after 28 days of curing. 
(ii) The young's modulus of conventional concrete can be determined by the CEB-FIP [63] code by using Eq. (8).

$$
E_{C}=0.85 \times 2.15 \times 10^{4} \times \sqrt[3]{\frac{f_{c}}{10}}
$$

(iii) According to the Indian Standard Building Code IS 456-2000 [60], young's modulus of normal weight conventional concrete can be estimated by Eq. (9).

$$
E_{C}=5000 \times \sqrt{f_{c}}
$$

(iv) Based on experimental results oven cured fly ash based GC, Hardjito et al. [27] proposed Eq. (10) to determine the young's modulus values.

$$
\mathrm{E}_{\mathrm{C}}=2707 \times \sqrt{\mathrm{f}_{\mathrm{c}}}+5300
$$

(v) To predict young's modulus of GC, Diaz-Loya et al. [64] proposed Eq. (11).

Therefore, the strength at a particular age has been considered as the value of compressive strength, while determining the young's modulus of GC using Eq. (11).

$$
E_{C}=0.037 \times \rho^{1.5} \times \sqrt{f_{c}}
$$

(vi) Lee and Lee [65] proposed Eq. (12) to predict the young's modulus of geopolymer concrete.

$$
E_{C}=5300 \times \sqrt[3]{f_{c}}
$$

(vii) Nath and Sarker [59] proposed Eq. (13) to predict the young's modulus of ambient-cured low-calcium fly ash blended GC.

$$
E_{C}=3510 \times \sqrt{f_{c}}
$$

The obtained result shows that the predicted model to determine young's modulus of fly ash-GGBS based GC from compressive strength; the following Eq. (14) was proposed. The proposed equation to determine the modulus of elasticity of GC is shown in Figure 6.

$$
\mathrm{E}_{\mathrm{C}}=3282 \times \sqrt{\mathrm{f}_{\mathrm{c}}} \mathrm{MPa}
$$

The results of elastic modulus of $100 \%$ fly ash and fly

\begin{tabular}{|c|c|c|c|c|c|c|c|c|c|c|c|}
\hline \multirow[b]{2}{*}{ Mix Id } & \multirow[b]{2}{*}{$\begin{array}{l}\text { Compre } \\
\text { ssive } \\
\text { Strengt } \\
\text { h (MPa) }\end{array}$} & \multirow[b]{2}{*}{$\begin{array}{c}\text { Mean } \\
\text { Density } \\
\text { of GC } \\
\mathbf{k g} / \mathbf{m}^{3}\end{array}$} & \multicolumn{9}{|c|}{ Young's Modulus (E) MPa } \\
\hline & & & $\begin{array}{c}\text { Experime } \\
\text { ntal }(28 \\
\text { days })\end{array}$ & $\begin{array}{c}\text { ACI 318- } \\
14 \text { [62] }\end{array}$ & $\begin{array}{c}\text { CEB-FIP } \\
\text { Model } \\
\text { [63] }\end{array}$ & $\begin{array}{c}\text { IS 456- } \\
2000[60]\end{array}$ & $\begin{array}{l}\text { Hardjito } \\
\text { et al [27] }\end{array}$ & $\begin{array}{c}\text { Diaz- } \\
\text { Loya et } \\
\text { al }[64]\end{array}$ & $\begin{array}{l}\text { Lee and } \\
\text { Lee [65] }\end{array}$ & $\begin{array}{c}\text { Nath } \\
\text { and } \\
\text { Sarker } \\
{[59]} \\
\end{array}$ & $\begin{array}{l}\text { This } \\
\text { paper }\end{array}$ \\
\hline $\mathbf{F}_{100} \mathbf{G}_{0}$ & 15.46 & 2310 & 13362.00 & 18771.16 & 21128.28 & 19659.60 & 15943.71 & 16151.93 & 13191.15 & 13801.04 & 12904.56 \\
\hline $\mathbf{F}_{90} \mathbf{G}_{10}$ & 17.14 & 2356 & 14297.30 & 20358.08 & 21866.69 & 20700.24 & 16507.11 & 17517.42 & 13652.16 & 14531.57 & 13587.64 \\
\hline $\mathbf{F}_{80} \mathbf{G}_{20}$ & 22.43 & 2377 & 68.21 & 23600.81 & 23915.72 & 23680.16 & 18120.44 & 20307.67 & 14931.45 & 16623.47 & 15543.66 \\
\hline $\mathbf{F}_{70} \mathbf{G}_{30}$ & 27.58 & 2375 & 17001.05 & 26137.32 & 25619.77 & 26258.33 & 19516.26 & 22490.25 & 15995.35 & 18433.35 & 17235.97 \\
\hline $\mathbf{F}_{60} \mathbf{G}_{40}$ & 31.61 & & 18164.60 & 28034.87 & 26810.13 & 28111.39 & 20519.50 & 24123.02 & 16738.53 & 19734.19 & 18452.31 \\
\hline $\mathbf{F}_{50} \mathbf{G}_{50}$ & 34.00 & 2389 & & 29277.38 & 27468.81 & 29154.76 & 21084.39 & 25192.16 & 17149.77 & 20466.64 & 19137.18 \\
\hline $\mathbf{F}_{40} \mathbf{G}_{60}$ & 36.25 & 2385 & 19520.62 & 30154.70 & 28061.25 & 30103.99 & 21598.30 & 25947.07 & 17519.65 & 21133.00 & 19760.26 \\
\hline $\mathbf{F}_{30} \mathbf{G}_{70}$ & 38.24 & 2392 & 20196.34 & 31107.79 & 28565.11 & 30919.25 & 22039.68 & 26767.17 & 17834.23 & 21705.31 & 20295.40 \\
\hline
\end{tabular}
ash-GGBS based geopolymer concrete from codes; previous literature and the present study are shown in Table 9.

It should be noted that, compared to fly ash-based GC fly ash-GGBS synthesized GC specimens are shown greater elastic modulus values.

Table 9. Elastic modulus of GC from codes, literature and present study

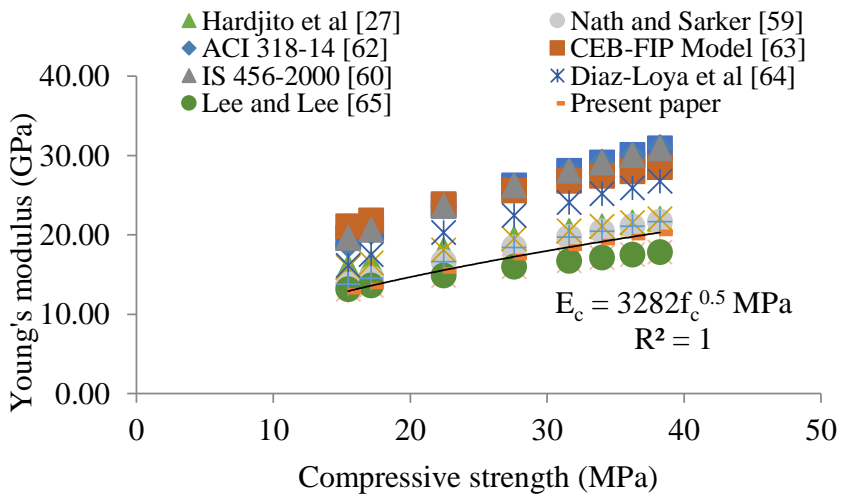

Figure 6. Comparison of predicted young's modulus

\section{CONCLUSIONS}

The data acquired from the experimental work on GC, the following conclusions are drawn:
Compared to all the mixes of Fly ash-GGBS synthesized $\mathrm{GC}\left(\mathrm{F}_{30} \mathrm{G}_{70}\right)$ attained higher compressive strength at 28 days of ambient curing i.e., $38.25 \mathrm{MPa}$ for the same mix spitting tensile and flexural strength values are $6.68 \mathrm{MPa}$ and 9.08 $\mathrm{MPa}$, respectively.

A non-linear numerical model was developed to calculate the empirical relationship between Splitting tensile strength $\left(f_{t}\right)$ Vs. Compressive strength $\left(f_{c}\right)$ and Flexural strength $\left(f_{f s}\right)$ Vs. Compressive strength $\left(f_{c}\right)$ of geopolymer concrete (GC) at 28 days of ambient curing. Thus, the proposed equations for ' $\mathrm{f}_{\mathrm{t}}$ ' $\mathrm{Vs}$. ' $\mathrm{f}_{\mathrm{c}}$ ' and ' $\mathrm{f}_{\mathrm{fs}}$ ' $\mathrm{Vs}$. ' $\mathrm{f}_{\mathrm{c}}$ ' $\mathrm{f}_{\mathrm{t}}=0.51 \mathrm{f}_{\mathrm{c}}^{0.66}$ and $\mathrm{f}_{\mathrm{fs}}=0.57 \mathrm{fc}^{0.74}$, respectively.

* Elastic modulus of GC is found to be $23-28 \%$ less than that of OPC concrete with similar compressive strength at 28 days of ambient curing. With an increase of compressive strength modulus of elasticity also increased.

\# The equations proposed by CEB-FIP model and ACI 318-14 code are overvalued for the elastic modulus of GC. Therefore, the proposed equation $\mathrm{E}_{\mathrm{c}}=3282 \times \sqrt{\mathrm{f}_{\mathrm{c}}}$ is used to predict the elastic modulus of fly ash-GGBS based geopolymer concrete in ambient curing condition. 


\section{ACKNOWLEDGMENT}

The authors are thankful to centre of excellence for permitting to do XRD analysis for materials and also thanking to the Vignan's Foundation for Science, Technology and Research (Deemed to be University) for their financial support for this research work and lab facility during our research work.

\section{REFERENCES}

[1] Juenger, M.C.G., Winnefeld, F., Provis, J.L., Ideker, J.H. (2010). Advances in alternative cementitious binders. Cement and Concrete Research, 41(12): 1232 1243. http://doi.org/10.1016/j.cemconres.2010.11.012

[2] Shi, C., Jiménez, A.F., Palomo, A. (2011). New cements for the 21st century: The pursuit of an alternative to Portland cement. Cement and Concrete Research, 41(15): 750-763 http://dx.doi.org/10.1016/j.cemconres.2011.03.016

[3] Duxson, P., Fernández-Jiménez, A., Provis, J.L., Lukey, G.C., Palomo, A., van Deventer, J.S.J. (2007) Geopolymer technology: The current state of the art. Journal of Material Science, 42(9): 2917-2933. http://dx.doi.org/10.1007/s10853-006-0637-z

[4] Phair, J.W., Van Deventer, J.S.J., Smith, J.D. (2000). Mechanism of polysialation in the incorporation of zirconia into fly ash based geopolymers. Indian Engineering Chemical Research, 39(8): 2925-2934. http://dx.doi.org/10.1021/ie990929w

[5] Hardjito, D., Wallah, S.E., Sumajouw, D.M.J., Rangan, B.V. (2004). On the development of fly ash-based geopolymer concrete. Materials Journal, 101(6): 467472. http://worldcat.org/oclc/13846872

[6] Palomo, A. Grutzeck, M.W., Blanco, M.T. (1999). Alkali-activated fly ashes, cement for the future. Cement and Concrete Research, 29(8): 1323-1329. http://dx.doi.org/10.1016/s 0008- 8846 (98)00243-9

[7] Davidovits, J. (1989). Geopolymers and geopolymeric materials. Journal of Thermal Analysis, 35(2): 429-441, http://dx.doi.org/10.1007/BF01904446

[8] Davidovits, J. (2008). Geopolymer Chemistry and Application. second ed., Institut Géopolymère, SaintQuentin, France.

[9] Yang, K.H., Song, J.K., Song, K.I. (2013). Assessment of $\mathrm{CO}_{2}$ reduction of alkali-activated concrete. Journal of Cleaner Production, 39(15): 265-272. http://dx.doi.org/10.1016/j.jclepro.2012.08.001

[10] Shaikh, F.U.A. (2016). Mechanical and durability properties of fly ash geopolymer concrete containing recycled coarse aggregates. International Journal of Sustainable Built Environment, 5: 277-287. https://doi.org/10.1016/j.ijsbe.2016.05.009

[11] Diaz, E.I., Allouche, E.N., Eklund, S. (2010). Factors affecting the suitability of fly ash as source material for geopolymers. $\quad$ Fuel, 89: 992-996. http://dx.doi.org/10.1016/j.fuel.2009.09.012

[12] Yip, C.K., Lukey, G.C., Provis, J.L., van Deventer, J.S.J. (2008). Effect of calcium silicate sources on geopolymerization. Cement Concrete Research, 38: 554-564. http://dx.doi.org/10.1016/j.cemconres.2007.11.001

[13] Palomo, A., Krivenko, P., Garcia-Lodeiro, I.,
Kavalerova, E., Maltseva, O., Fernández-Jiménez, A. (2014). A review on alkaline activation: New analytical perspectives. Mater. Constr., 64(315): 1022-1031. http://dx.doi.org/10.3989/mc.2014.00314

[14] Fernandez-Jimenez, A., García-Lodeiro, I., Palomo, A. (2007). Durability of alkali-activated fly ash cementitious materials. J. Mater. Sci., 42(9): 3055-3065. http://dx.doi.org/10.1007/s10853-006-0584-8

[15] Bascarevic, Z., Komljenovic, M., Miladinovic, Z., Nikolic, V., Marjanovic, N., Zujovic, Z., Petrovic, R. (2013). Effects of the concentrated $\mathrm{NH}_{4} \mathrm{NO}_{3}$ solution on mechanical properties and structure of the fly ash based geopolymers. Construction and Building Materials, 41(3): 570-579. http://dx.doi.org/10.1016/j.conbuildmat.2012.12.067

[16] Komljenovic, M., Bascarevic, Z., Bradic, V. (2010). Mechanical and micro structural properties of alkaliactivated fly ash geopolymers. J Hazard Mater, 181(13): http://dx.doi.org/10.1016/j.jhazmat.2010.04.064

[17] Sarker, P.K., Haque, R., Ramgolam, K.V. (2013). Fracture behaviour of heat cured fly ash based geopolymer concrete. Materials and Design, 44: 580586. http://dx.doi. org/10.1016/j.matdes.2012.08.005

[18] Kovalchuk, G., Fernández-Jiménez, A., Palomo, A. (2007). Alkali-activated fly ash: Effect of thermal curing conditions on mechanical and microstructural development. $\quad$ Fuel, 86(3): 315-22. http://dx.doi.org/10.1016/j.fuel.2006. 07.010

[19] Yunsheng, Z., Wei, S., Zongjin, L. (2010). Composition design and microstructural 724 characterization of calcined kaolin-based geopolymer cement. Appl Clay Sci, $\quad$ 47(3-4): 271-275. http://dx.doi.org/10.3390/min8100444

[20] Sarker, P.K. (2011), Bond strength of reinforcing steel embedded in geopolymer concrete. Mater. Struct., 44(5): 1021-1030. http://dx.doi.org/10.1617/s11527-010-96838

[21] Fernández-Jiménez, A., Palomo, A. (2005). Composition and microstructure of alkali activated fly ash binder: Effect of the activator. Cement and Concrete Research, 35(10): 1984-92. https://doi.org/10.1016/j.cemconres.2005.03.003

[22] M. Venu, T.D. Gunneswara Rao (2017). Tieconfinement aspects of fly ash-GGBS based geopolymer concrete short columns. Construc. and Build. Materials, 151: 28-35. http://dx.doi.org/10.1016/j.conbuildmat.2017.06.065

[23] Vijai, K., Kumutha, R., Vishnuram, B.G. (2010). Effect of types of curing on strength of geopolymer concrete. International Journal Physics Science, 5(9): 1419-1423.

[24] Nath, P., Sarker, P.K. (2014). Effect of GGBFS on setting, workability and early strength properties of fly ash geopolymer concrete cured in ambient condition. Construction and Building Materials, 66: 163-171. http://dx.doi.org/10.1016/j.conbuildmat.2014.05.080

[25] Sofi, M., van Deventer, J.S.J., Mendis, P.A., Lukey, G.C. (2007). Engineering properties of inorganic polymer concretes (IPCs). Cement and Concrete Research, 37(2): 251-257. http://dx.doi.org/10.1016/j.cemconres.2006.10.008

[26] Fernandez-Jimenez, A.M., Palomo, A., Hombrados, C.L. (2006). Engineering properties of alkali-activated fly ash concrete. ACI Mater. J., 103(2): 106-112. 
http://dx.doi.org/10.14359/15261

[27] Hardjito, D., Wallah, S.E., Sumajouw, D.M.J., Rangan, B.V. (2004). The stress-strain behaviour of fly ashbased geopolymer concrete, in: A.J. Decks, H. Hao (Eds.), Development in Mechanics of Structures and Materials, A.A. Balkema Publishers, Leiden, South Holland, 831-834.

[28] Puertas, F., Amat, T., Fernández-Jiménez, A., Vázquez, T. (2003). Mechanical and durable behaviour of alkaline cement mortars reinforced with polypropylene fibres. Cement Concrete Research, 33: 2031-2036. http://dx.doi.org/10.1016/S0008-8846(03)00222-9

[29] Bondar, D., Lynsdale, C.J., Milestone, N.B., Hassani, N., Ramezanianpour, A.K. (2011). Engineering properties of alkali-activated natural pozzolan concrete. ACI Materials Journal, 108(1): 64-72.

[30] Singh, N.B. (2018). Fly ash-based geopolymer binder: A future construction material. Minerals, 8: 299-307. http://dx.doi.org/10.3390/min8070299

[31] Kumar, V., Mathur, M., Sinha, S.S., Dhatrak, S. (2005) Fly Ash: An environmental savior. Fly Ash Utilisation Programme (FAUP), TIFAC, DST, Fly Ash India, New Delhi, IV: 1.1-1.4. https://books.google.co.in.

[32] Chindaprasirt, P., Chareerat, T., Siricicatnanon, V. (2007). Workability and strength of coarse high calcium fly ash geopolymer. Cement Concrete Compos., 29: 224-229.

[33] Hardjito, D., Rangen, B.V. (2005). Properties of lowcalcium fly ash-based geopolymer concrete, Research Report GC 1Faculty of Engineering Curtain University of Technology Perth, Australia.

[34] IS: 2386 - 1963, Indian Standard Methods of Test for Aggregates for concrete, Bureau of Indian standards, New Delhi.

[35] IS 383-1970 Specification for coarse and fine aggregates from natural sources for concrete, Bureau of Indian Standards, New Delhi.

[36] Subhash V. Patankar, Yuwaraj M. Ghugal and Sanjay S. Jamkar (2015). Mix design of fly ash based geopolymer concrete. Advances in Structural Engineering, 16191634, Springer India. http://dx.doi.org/10.1007/978-81322 2187-6_123

[37] IS 10262-1970 recommended guidelines for concrete mix design on for coarse and fine aggregates from natural sources for concrete, Bureau of Indian Standards, New Delhi.

[38] Patankar, S.V., Jamkar, S.S., Ghugal, Y.M. (2014). Selection of suitable quantity of water, degree and duration of heat curing for geopolymer concrete production. In: Proceedings of 3rd international conference on recent trends in engineering and technology, ICRTET.

[39] IS 1199-1959, Indian Standard Methods of Sampling and Analysis of Concrete, Eleventh Reprint November1991, Bureau of Indian standards, New Delhi 110002.

[40] IS: 516-1959, Indian Standard Methods of Tests for Strength of Concrete, Bureau of Indian Standards, New Delhi.

[41] ASTM C496/C496M-17, Standard Test Method for Splitting Tensile Strength of Cylindrical Concrete Specimens, American Society for Testing and Materials.

[42] ASTM C78 /C78M-18, Standard Test Method for Flexural Strength of Concrete (Using Simple Beam with Third-Point Loading), American Society for Testing and Materials.

[43] Patankar, S.V., Jamkar, S.S., Ghugal, Y.M. (2012). Effect of sodium hydroxide on flow and strength of fly ash based geopolymer mortar. Journal of Struct. Eng., 39(1): 7-12. http://dx.doi.org/10.1155/2014/938789

[44] Bakharev, T., Sanjayan, J.G., Cheng, Y.B. (2003). Resistance of alkali-activated slag concrete to acid attack. Cement Concrete Research, 33: 1607-1611. https://www.ijraset.com.

[45] Shi, C. (2003). Corrosion resistance of alkali-activated slag cement. Advances in Cement Rese., 15(2): 77-81. http://dx.doi.org/10.1680/adcr.2003.15.2.77

[46] Bernal, S.A., Rodríguez, E.D., de Gutierrez, R.M., Provis, J.L. (2012). Performance of alkali-activated slag mortars exposed to acids. Journal of Sustain. Cem. Mater., $\quad 1$ : 37-41. http://dx.doi.org/10.1080/21650373.2012.747235

[47] ASTM C469/C469M-10, Standard Test Method for Static Modulus of Elasticity and Poisson's Ratio of Concrete in Compression, ASTM Standards. ASTM International, West Conshohocken, PA, 2010.

[48] ACI Committee 363, State of the art report on high strength concrete (ACI 363R-92), American Concrete Institute, Farmington Hills, Mich., pp.55, 1992.

[49] ACI Committee 318, Building code requirements for structural concrete (ACI 318R-99), American Concrete Institute, Farmington Hills, Mich., pp. 391, 1999.

[50] Carino. N.J., Lew. H.S. (1982). Re-examination of the relation between splitting tensile and compressive strength of normal weight concrete. ACI Materials Journal, 79(3): 214-219.

[51] Ahmad. S.H., Shah, S.P. (1985). Structural properties of high strength concrete and its implication for precast prestressed concrete. PCI Journal, 30(6): 92-119.

[52] Gardner, N.J, Sau, P.L., Cheung, M.S. (1988). Strength development and durability of concretes cast and cured at $0^{\circ} \mathrm{C}$. ACI Materials Journal, 85(6): 529-536.

[53] Gardner, N.J. (1990). Effect of Temperature on the Early Age Properties of Type I, Type III and Type I/ Fly ash Concretes. ACI Materials Journal, 87(1): 68-78.

[54] Oluokun, F.A, Burdette, E.G., Deatherage, J.H. (1991). Splitting tensile strength and compressive strength relationships at early ages. ACI Materials Journal, 88(2): 115-121.

[55] Mhaiskar, S.Y., Naik, D.D. (2012). Studies on correlation between flexural tensile strength and compressive strength of concrete. The Indian Concrete Journal, 86(6): 1-6.

[56] Mohd, A., El Hadi, K.M., Mallick, J., Hasan, M.A., Ahmed, A. (2012). Evaluating the co-relationship between concrete flexural tensile strength and compressive strength. International Journal of Structural Engineering, http://dx.doi.org/10.1504/IJSTRUCTE.2014.060902

[57] Juki, M.I., Awang, M., Mahamad, M.K.A., Boon, K.H., Othman, N., Kadir, A.A., Roslan, M.A., Khalid, F.S. (2013). Relationship between compressive, splitting tensile and flexural strength of concrete containing granulated waste polyethylene terephthalate (PET) bottles as fine aggregate. Advanced Materials Research, 795: 356-359.

[58] Raphael, J.M. (1984). Tensile strength of concrete. ACI Materials Journal, 81(2): 158-165.

[59] Nath, P., Sarker, P.K. (2016). Flexural strength and 
elastic modulus of ambient-cured blended low-calcium fly ash geopolymer concrete. Construction and Building Materials.

http://dx.doi.org/10.1016/j.conbuildmat.2016.11.034

[60] IS 456-2000 Plain and Reinforced Concrete-Code of Practice is an Indian Standard code of practice for general structural use of plain and reinforced concrete.

[61] Olivia, M., Nikraz, H. (2012). Properties of fly ash geopolymer concrete designed by Taguchi method. Materials and Design, 36(4): 191-198. http://dx.doi.org/10.1016/j.matdes. 2011.10.036

[62] ACI 318-14 (2014). Building Code Requirements for Structural Concrete and Commentary, American Concrete Institute, Farmington Hills, MI 48331, U.S.A.

[63] CEB-FIP Model Code, Comite Euro-International Du Beton, 1990, pp. 39.

[64] Diaz-Loya, E.I., Allouch, F.N., Vaidya, S. (2011). Mechanical properties of fly-ash based geopolymer concrete. ACI Materials Journal, 108(3): 279-287 http://dx.doi.org/10.14359/ 51682495

[65] Lee, N.K., Lee, H.K. (2013). Setting and mechanical properties of alkali-activated fly ash/ slag concrete manufactured at room temperature. Construction and Building Materials, 47: 1201-1209. http://dx.doi.org/10.1016/j.conbuildmat.2013.05.107

\section{NOMENCLATURE}

GC Geopolymer concrete

$\mathrm{p} \quad$ Ultimate load (KN)

1 Supported length $(\mathrm{mm})$

b Width of the beam specimen ( $\mathrm{mm})$

$\mathrm{d}$ Depth of the beam specimen $(\mathrm{mm})$

$\mathrm{f}_{\mathrm{t}} \quad$ Splitting tensile strength

$\mathrm{f}_{\mathrm{ft}} \quad$ Flexural strength

$\mathrm{f}_{\mathrm{c}} \quad$ Compressive strength 